\title{
Preparation of Low Energy Cement Clinker from Paper Industry Waste Materials
}

\author{
Prabhat Vashistha ${ }^{1}$, Singh $\mathrm{SK}^{2 *}$ and Vivek Kumar ${ }^{3}$ \\ ${ }^{1}$ Research Associate, CSIR-Central Building Research Institute, India \\ ${ }^{2}$ Professor, AcSIR CSIR-Central Building Research Institute, India \\ ${ }^{3}$ Professor, Indian Institute of Technology, India
}

ISSN: 2639-0574

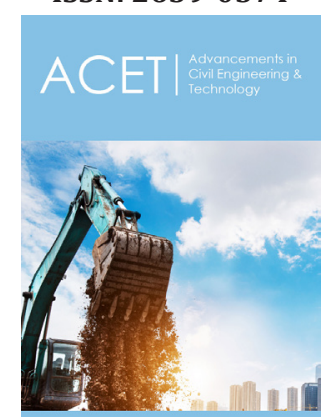

${ }^{* 1}$ Corresponding author: Singh SK, Professor, AcSIR CSIR-Central Building Research Institute, India

Submission: 韭 March 9, 2020

Published: 㭗April 14, 2020

Volume 4 - Issue 2

How to cite this article: Prabhat V, Singh S, Vivek K. Preparation of Low Energy Cement Clinker from Paper Industry Waste Materials. Adv Civil Eng Tech. 4(2). ACET.000583. 2020.

DOI: 10.31031/ACET.2020.04.000583

Copyright@ Singh SK, This article is distributed under the terms of the Creative Commons Attribution 4.0 International License, which permits unrestricted use and redistribution provided that the original author and source are credited.

\begin{abstract}
The Kraft process-based paper production generates considerable amount of waste. The chemical recovery section produces lime sludge while fly ash is being generated in the boiler through combustion of biomass for electricity production. The final utilisation of such waste materials is significant concern, since landfilling is becoming less effective destination due to strict environmental regulations. Determined by this scenario, industries are considering more sustainable solutions, such as application of waste material in manufacturing of distinct products. In this work, the lime sludge and fly ash tested as raw materials for cement clinker synthesis and mortar preparation from synthesised cement clinker. Firstly, the detailed characterisation of waste materials was performed, on the basis of characterisation distinct mixtures of materials were prepared. The formulated mixtures then fired at $1000{ }^{\circ} \mathrm{C}$ and $1100{ }^{\circ} \mathrm{C}$ to get cementitious clinkers. The clinker was processed at relatively lower temperature than generally used in the industrial synthesis of clinker due to the presence of mineralising impurities in fly ash and lime sludge. The cement was prepared from the synthesised clinker and applied to produce the mortars that advanced in adequate mechanical strength and did not divulge signs of deterioration or durability weaknesses.
\end{abstract}

Keywords: Paper industry; Waste materials; Lime sludge; Fly ash; Clinker; Cement; Mortar

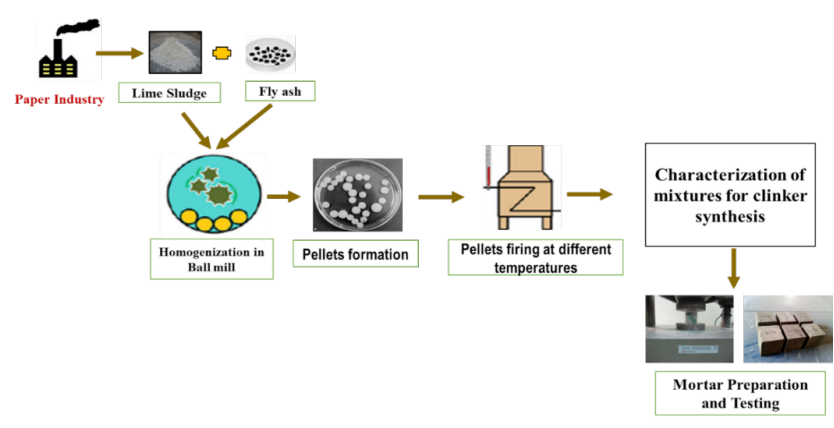

Graphical Abstract

\section{Introduction}

The pulp and paper industry are among the largest consumers of water and energy. In the process of paper manufacturing, industries consume almost $5 \%$ of the total energy available for global industrial sector and emit approximately $2 \%$ of global $\mathrm{CO}_{2}$ emission on the planet [1]. The increase in demand of paper products is the reason for existence of these characteristics [2]. To meet this high demand, in 2015 the world production of paper and paperboard exceeded 390 million tons [2,3]. In virgin paper manufacturing processes, the chemical recovery stage represents the largest source of pollution in the whole process; generation of huge quantity of lime sludge takes place in this process [4]. Figure 1 demonstrates lime sludge generation process [5]. The green liquor formed during the chemical recovery section by dissolving the smelt (chemicals) in the molten residual of pulping process (black liquor). The causticization process converts the green liquor $\left(\mathrm{Na}_{2} \mathrm{CO}_{3}\right)$ into the white liquor $(\mathrm{NaOH})$. In this process, lime sludge produces during the conversion of green liquor into the white liquor through causticization reaction. The smelt $\left(\mathrm{Na}_{2} \mathrm{CO}_{3}\right)$ of green liquor reacts with $\mathrm{CaO}$ to form $\mathrm{NaOH}$, which is known as white liquor, and residue of the reaction $\left(\mathrm{CaCO}_{3}\right)$ precipitated 
in the form of lime sludge [5-7]. Convent ally, limekiln is used in industries to recycle the lime sludge to reuse it as $(\mathrm{CaO})$ in the recovery process (Figure 2).

Agro residue-based paper mills, release high silica (5-10\%) in lime sludge and poses significant problems such as scaling in lime kiln [5]. This is why industries are disposing off the lime sludge and becoming a threat for environment. Various studies have been reported over the past three decades, considering the use of lime sludge from industries as a construction material. Talukdar [8] studied the feasibility of manufacture of lightweight aggregates using lime sludge mixed with cementitious materials. Aggregates of density $0.7 \mathrm{~g} / \mathrm{m}^{3}$ to $1.03 \mathrm{~g} / \mathrm{m}^{3}$ were produced. Nevertheless, this kind of utilisation of lime sludge are very limited due to which lime sludge application remains an area of interest for research $[9,10]$. Many other studies focused on application of as received lime sludge in concrete for replacement of cement and reported the reduction of compressive strength with increasing amount of lime sludge. The concentration decline in silicates due to application of lime sludge is possible reason for strength reduction [4,11]. While several studies focused on the replacement of fine aggregates by lime sludge and found its limitation up to $20 \%$ replacement [12]. Therefore, it is needful to develop novel methods to upsurge the utilisation of lime sludge.

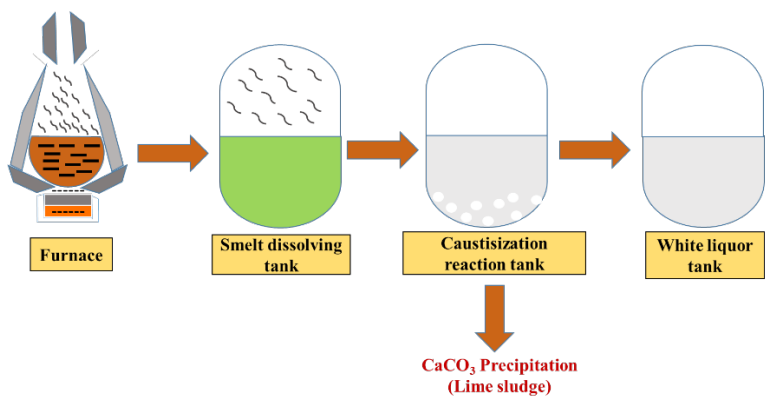

Figure 1: Generation process of lime sludge.

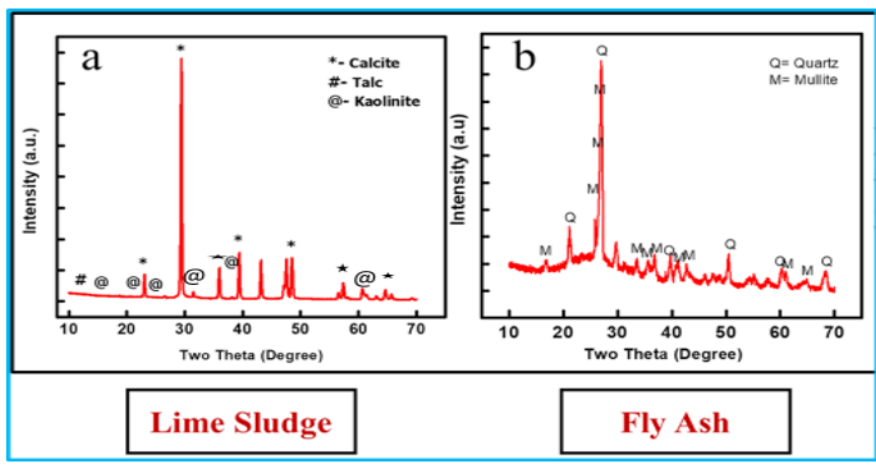

Figure 2: XRD spectrum of lime sludge and fly ash.

Researchers extended the research and used different type of ash in combination with lime sludge in mortar and concrete [1315]. Several studies reported application of lime sludge with fly ash in formation of belite based cementitious binder. Leire [16] had undertaken a study on the synthesis of eco-clinker from the thermal treatment of waste materials like lime sludge, biological sludge, and fly ash. The blend with 49\% lime sludge, 20\% fly ash and $30 \%$ biological sludge showed the best clinkering factor for synthesis of belite based clinker. The mortars were also produced from synthesized clinker, which satisfied the requirement of indoor and outdoor application of clinker in plastering. Simao [17] also tried for the synthesis of eco-clinker by combined utilisation of lime sludge with coal biomass ash. Vashistha [18] also utilised the boiler bottom ash for the synthesis of nano-silica and produced belite based clinker by the sintering of lime sludge and synthesized nano-silica at relatively lower temperature. All these studies were focused on either very high sintering temperature for alite-belite based clinker or synthesis of less effective belite based clinker. Both the process is less effective on economical point of view and solution for these problems are the base of current study.

Aim of the present study is to utilise the lime sludge and fly ash in a gainful manner. Different composition mixture of lime sludge and fly ash were prepared for the synthesis of eco-clinker. The prepared mixtures were fired at temperatures of $1000{ }^{\circ} \mathrm{C}$ and $1100{ }^{\circ} \mathrm{C}$ to check the clinker synthesis, applied temperature is reasonably less than the temperature used to prepare the cement clinker conventionally. The eco-clinker will help in the reduction of global warming due to emission of carbon dioxide, which ultimately causes the depletion of ozone layer $[19,20]$. This study is also intended to explore the possibility of large-scale utilisation of solid waste materials. 


\section{Experimental Program}

\section{Materials and Methods}

The lime sludge used in this study is an outcome of the causticization process in recovery section of the M/s Ruchira Paper Industry Kalaamb. Fly ash was also collected from the boiler of the same industry. The materials were dried in a hot air oven with controlled temperature of $105{ }^{\circ} \mathrm{C}$ until its dry mass remained constant. After drying, the materials were ground separately in a Willeye mill (Tecnal, model Te-651) with a 10 Mesh sieve. Thermogravimetry (TGA), X-ray fluorescence spectrometry (XRF), X-ray diffraction (XRD), were used to analyse dry raw materials. TGA was performed by an equipment, TGA Netzsch, model STA 409 with the heating rate of $10{ }^{\circ} \mathrm{Cmin}^{-1}$, which was started from room temperature to $1000{ }^{\circ} \mathrm{C}$. The test was performed with ovendried samples within alumina crucibles and without air. In order to accomplish the synthesis of nano-silica and belite, raw materials were characterised to determine their chemical, thermal, and mineralogical properties. The chemical characterisation of raw materials was conducted using the non-destructive analytical technique. The XRD was performed through the equipment named Bruker diffractometer, model D8, with 2 theta gonio-meter. The conditions were $40 \mathrm{kV}$ and $40 \mathrm{~mA}$ for the employment of X-ray radiation through alpha-copper. The room temperature was kept at $25{ }^{\circ} \mathrm{C}$. For the XRF tests, the equipment used was Bruker S4 Pioneer spectrometer. X'Pert High Score Plus software was used for the crystalline phase identification. The quantitative analysis for present phases was also performed by Rietveld refinement with the GSAS-EXPGUI software. Up to 40 independent variables were refined: scale-factors, zeropoint,15 coefficients of the shifted Chebyschev function to fit the background, unit cell parameters, profile coefficients (one Gaussian, Gw and 2 Lorentzian terms, Lx and Ly). The fitting accuracy is represented by c2 (goodness of fit). The elemental composition of the materials was determined through this equipment by measuring the fluorescent emitted from the sample, when it is exited through a source. The samples were dried in an oven at $105{ }^{\circ} \mathrm{C} \pm 5{ }^{\circ} \mathrm{C}$, ground and sieved with 200Mesh. The average particle size and particle size distribution of raw materials were determined by a laser particle size analyser (Horiba LA-950V2).

\section{Clinker preparation}

As received lime sludge was utilised in clinker preparation, while fly ash was previously sieved at 75 micron. Initially, materials were mixed to create a homogeneous mixture. A porcelain jar mill $(250 \mathrm{~mL})$ was used to mix the raw materials at the rotation of 400rpm for 60 minutes with the 10:1 alumina ball and powder ratio to make a fine homogeneous powder. Table 1 represents the proportion of the mixtures which were formed to achieve the following objectives: A desirable clinker (belite-alite rich), derived from the composition of waste materials; consumption of highest amount of lime sludge and fly ash. These homogenized mixtures were used to prepare the pellets by applying the pressure of $9000 \mathrm{~kg} / \mathrm{cm}^{2}$ through hydraulic press. The prepared pellets were kept in the muffle furnace at the temperature of $1000^{\circ} \mathrm{C}$ and 1100 ${ }^{\circ} \mathrm{C}$ for $1 \mathrm{hr}$ for solid-state reactions. The fired pellets were crushed after rapid cooling and fine powder of each mixture was stored in airtight container for characterisation. The blend characterised with best composition of alite and belite synthesis (F-fired blend) was utilised for binder fabrication.

\section{Mortar preparation}

The fired mixture with best alite and belite composition was utilised to compose the cement. According to EN197-1:201, there are two main categories of Portland cement, one is CEM I another one is CEM II. The main constituents of CEM I (ordinary Portland cement) are (95-100wt. \% clinker and 0-5wt. \% minor supplementary ingredients (e.g., gypsum) while in case of CEM II (Portland-composite cement) the percentage of clinker differs from 65 to 94 wt. \%, contingent to the cement type, numerous other pozzolanic ingredients. In present work, the CEM I type of cement was prepared. The fired clinker powder was milled and sieved with 63 micron and then to prepare the cement $5 \%$ of gypsum was added. The composition of prepared mortars has given in Table 2 .

Table 1: Composition of the mixtures.

\begin{tabular}{|c|c|c|}
\hline Formulation & Fly Ash (wt. \%) & Lime Sludge (wt. \%) \\
\hline F1 & 40 & 60 \\
\hline F2 & 50 & 50 \\
\hline F3 & 60 & 40 \\
\hline
\end{tabular}

Table 2: Mortar composition.

\begin{tabular}{|c|c|}
\hline Material & Ratio (by wt.) \\
\hline Developed eco-cement & 1 \\
\hline $\begin{array}{c}\text { Calibrated sand }\left(\mathrm{D}_{50}=1.15 \mathrm{~mm}, \mathrm{D}_{\max }\right. \\
=2.0 \mathrm{~mm})\end{array}$ & 4.5 \\
\hline Water/cement ratio & 0.85 \\
\hline
\end{tabular}

\section{Results and Discussion}

\section{Characterization of raw materials}

Table 3 represents the chemical composition of as received waste materials, which also reflects their generation process. As discussed earlier, lime sludge is co-product of causticization reaction in chemical recovery section of paper industry, in which calcium oxide converted into calcium carbonate. This is why, the lime sludge imputes $47.10 \%$ calcium oxide with loss of ignition (LOI) of $43.18 \%$, the decomposition of calcium carbonate resulted in the loss of ignition of LS. While fly ash generation takes place in the boiler through the ignition of organic raw materials like coal and agricultural waste. The fly ash consists of silicon dioxide $\left(\mathrm{SiO}_{2}, 49.11 \%\right)$, aluminium oxide $\left(\mathrm{Al}_{2} \mathrm{O}_{3}, 10.13 \%\right)$, Iron oxide $\left(\mathrm{Fe}_{2} \mathrm{O}_{3}\right.$, $6.05 \%$ ) and Magnesium Oxide (MgO, 0.95\%) with 15.35\% loss of ignition (LOI) loss of ignition in case of fly ash is due to the removal of moisture content and removal of residual organic content present due to incomplete combustion of coal $[9,10]$.

The objective of the study is dependent on calcium of the lime sludge and silica, alumina of the fly ash. The XRD of LS and fly ash illustrated in the Figure 3. The calcite and kaolinite were found as 
the major phase in the lime sludge spectrum while fly ash spectrum showed the mullite and quartz as the major phases. According to the outcome of XRD spectrum it can be inferred that XRD and XRF of the fly ash and lime sludge are in consistency, both techniques revelled the presence of significant amount of silica, alumina and calcium in both raw materials [11,12]. The cumulative particle size distribution of LS and fly ash are illustrated in Figure 3 \& 4 . The particle size of LS varies from $5.1 \mu \mathrm{m}$ to $262.37 \mu \mathrm{m}$ with an average particle size range (D50) of $36.65 \mu \mathrm{m}$. FA had particle size distribution from $4.3 \mu \mathrm{m}$ to $260.68 \mu \mathrm{m}$ with average particle size (D50) of $46.23 \mu \mathrm{m}$.

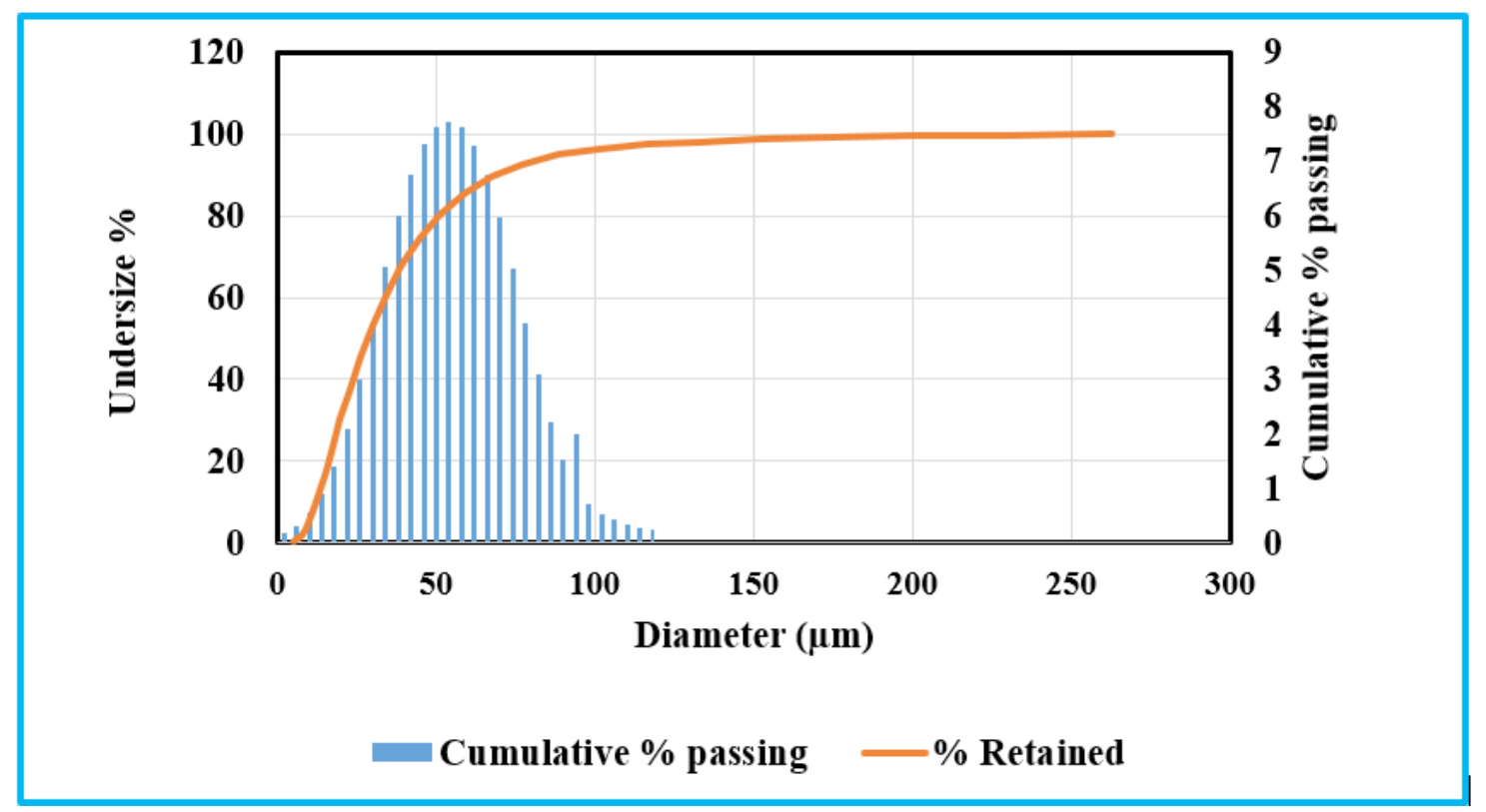

Figure 3: Particle size analysis of lime sludg

Table 3: Chemical composition of the dried wastes obtained by XRF.

\begin{tabular}{|c|c|c|c|c|c|c|c|c|c|c|c|}
\hline \multirow{2}{*}{$\begin{array}{c}\text { Raw } \\
\text { Materials }\end{array}$} & \multicolumn{11}{|c|}{ Oxide Content (\% Weight) } \\
\hline & $\mathrm{Al}_{2} \mathrm{O}_{3}$ & $\mathrm{SiO}_{2}$ & $\mathrm{CaO}$ & $\mathrm{Fe}_{2} \mathrm{O}_{3}$ & $\mathrm{MgO}$ & $\mathrm{SO}_{3}$ & $\mathrm{MnO}$ & $\mathrm{NiO}$ & $\mathrm{Na}_{2} \mathrm{O}$ & $\mathrm{P}_{2} \mathrm{O}_{5}$ & LOI $(\%)$ \\
\hline Lime sludge & 0.40 & 7.74 & 47.10 & 0.20 & 0.02 & 0.23 & 0.02 & 0.02 & 0.88 & 0.29 & 43.18 \\
\hline Fly ash & 10.13 & 49.11 & 17.19 & 6.05 & 0.95 & 1.11 & 0.02 & 0.05 & 0.45 & 0.39 & 15.35 \\
\hline
\end{tabular}

The thermal behaviour of LS and FA are studied in Figure 5 \& 6. TGA curve of LS sample indicates the initial mass loss of $7.26 \%$, which is attributed to moisture removal. A strong endothermic peak dominates at $787^{\circ} \mathrm{C}$ in DTA curve, which is characteristic of the decomposition reaction of calcite $\left(\mathrm{CaCO}_{3}\right)$ to calcium oxide. It reflects a significant mass loss of approximately $40 \%$. The total mass loss percentage is in consistency with the LOI (43\%). In the case of fly ash, it suffers less conversion upon heating with a total mass loss of $16.93 \%$ which is also in coordination with LOI (Loss of Ignition) of XRF. The reduction in mass $(13.19 \%)$ from $430{ }^{\circ} \mathrm{C}$ to $700{ }^{\circ} \mathrm{C}$ caused by the burning of residual bituminous coal present in the fly ash and conversion of calcium carbonate $\left(\mathrm{CaCO}_{3}\right)$ to calcium oxide ( $\mathrm{CaO})[21,22]$. DTA curve shows exothermic peak at $596{ }^{\circ} \mathrm{C}$ that is the outcome of organic matter degradation. Due to the presence of high percentage of quartz in fly ash, it reflects the relatively inert nature with heat treatment. Mass loss of $43 \%$ and
$16.93 \%$ for LS and fly ash respectively are consistent with the loss of ignition (LOI), which is determined through chemical analysis reported in Table 1.

\section{Characterization of fired powder mixtures}

$\mathrm{F} 1, \mathrm{~F} 2$ and $\mathrm{F} 3$ treated at $1000{ }^{\circ} \mathrm{C}$ and $1100{ }^{\circ} \mathrm{C}$, according to the transitions indicated by the X-ray diffraction, the formation of clinker takes place in several steps. Following are the main reactions [23]:

A. Decomposition of clay minerals after dehydration and de-hydroxylation at $100-850{ }^{\circ} \mathrm{C}$ to get reactive oxides like $\mathrm{SiO}_{2}$ and $\mathrm{Al}_{2} \mathrm{O}_{3}$

B. Decomposition of carbonate from $550-950{ }^{\circ} \mathrm{C}$. Formation of belite $\left(\mathrm{C}_{2} \mathrm{~S}\right)$ from $850-1100^{\circ} \mathrm{C}$ by the reaction of free $\mathrm{CaO}$ and $\mathrm{SiO}_{2}$

$$
2 \mathrm{CaO}+\mathrm{SiO}_{2} \rightarrow 2 \mathrm{CaO} \cdot \mathrm{SiO}_{2}(1)
$$


C. Formation of tricalcium aluminate $\left(3 \mathrm{CaO} \cdot \mathrm{Al}_{2} \mathrm{O}_{3}\right)$ and ferrite $\left(4 \mathrm{CaO} \cdot \mathrm{Al}_{2} \mathrm{O}_{3} \cdot \mathrm{Fe}_{2} \mathrm{O}_{3}\right)$ from $\left(850-1100{ }^{\circ} \mathrm{C}\right)$.

$$
\begin{gathered}
\mathrm{CaO} \cdot \mathrm{Al}_{2} \mathrm{O}_{3}+2 \mathrm{CaO} \rightarrow 3 \mathrm{CaO} \cdot \mathrm{Al}_{2} \mathrm{O}_{3}(2) \\
\mathrm{CaO} \cdot \mathrm{Al}_{2} \mathrm{O}_{3}+3 \mathrm{CaO}+\mathrm{Fe}_{2} \mathrm{O}_{3} \rightarrow 4 \mathrm{CaO} \cdot \mathrm{Al}_{2} \mathrm{O}_{3} \cdot \mathrm{Fe}_{2} \mathrm{O}_{3}(3)
\end{gathered}
$$

D. Formation of alite crystals (C3S) by the combination of $\mathrm{C} 2 \mathrm{~S}$ with free lime from $1000{ }^{\circ} \mathrm{C}$ onwards.

$$
\mathrm{CaO}+2 \mathrm{CaO} \cdot \mathrm{SiO}_{2} \rightarrow 3 \mathrm{CaO} \cdot \mathrm{SiO}_{2}(4)
$$

Figure 7-10 represents the XRD spectrum of the fired blends $\mathrm{F} 1, \mathrm{~F} 2$ and F3 at the temperature of $1000{ }^{\circ} \mathrm{C}$ and $1100{ }^{\circ} \mathrm{C}$. The spectrums depict the characteristic peaks of aluminates and silicates compounds, which found in cementitious clinker. Belite or dicalcium silicate $\left(\mathrm{C}_{2} \mathrm{~S}\right)$ found as the polymorph (belite) while alite (Tricalcium silicate $\mathrm{C}_{3} \mathrm{~S}$ ) displays as the monoclinic polymorph (M3). Alite (C3S) exhibits six different polymorphs from room temperature up to $1100^{\circ} \mathrm{C}$ : three triclinic forms (T1, T2, T3), two monoclinic forms (M1 and M2) and one rhombohedra (R). On the fast cooling of the clinker, some impurities may stabilize the high temperature form of the alite. $\mathrm{MgO}$ present in the fly ash as impurity stabilized the alite (M3) as pure compound [24-26]. Figure 7 demonstrates the different polymorphic forms and synthesis temperature of synthesis for alite pure form.

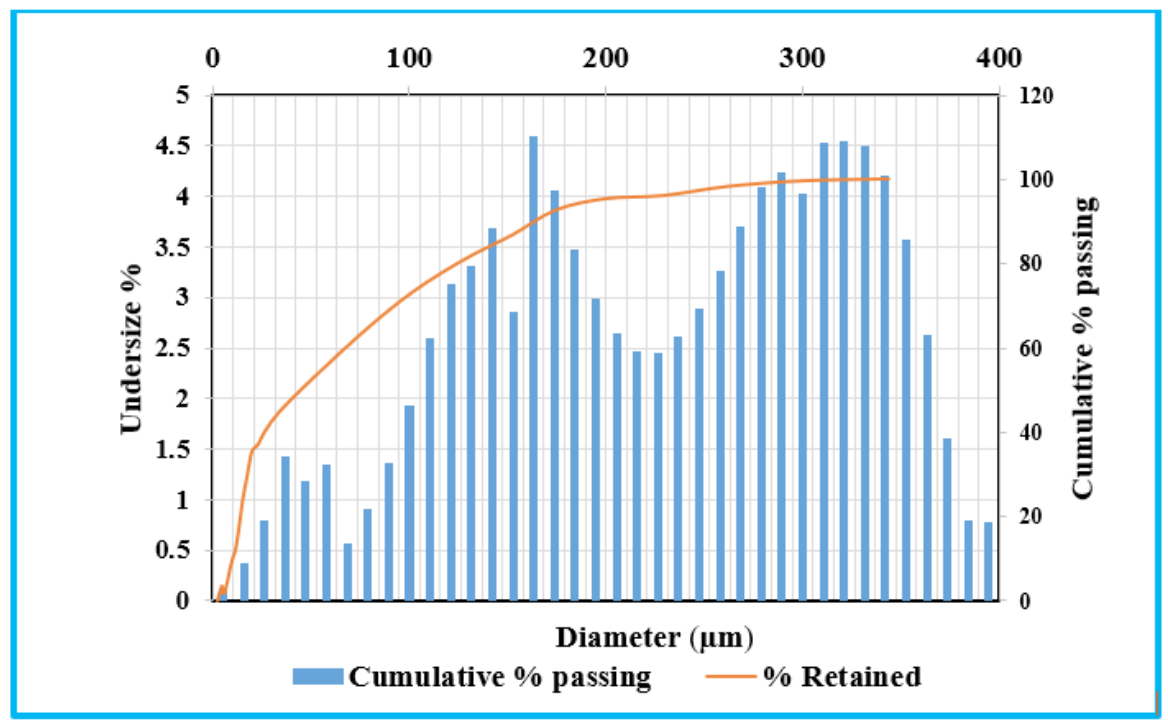

Figure 4: Particle size analysis of fly ash.

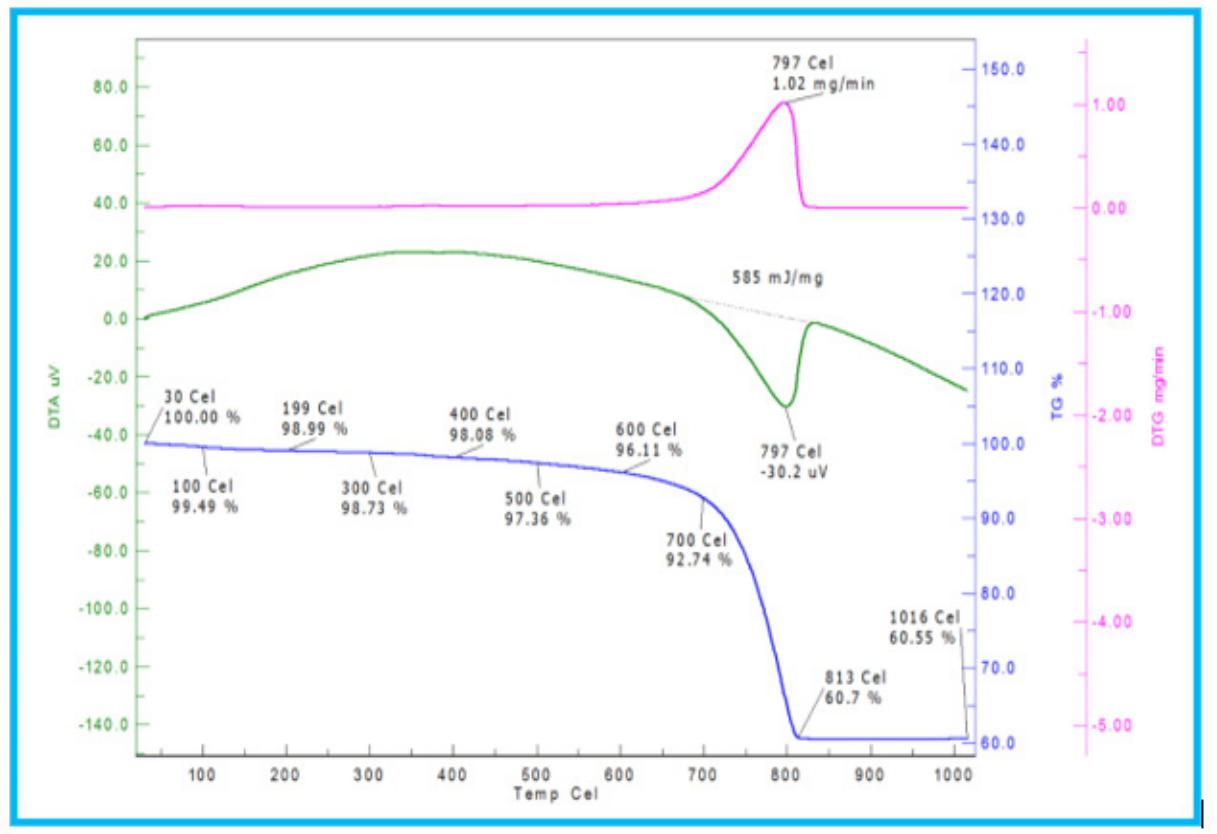

Figure 5: TGA/ DTA of lime sludge. 


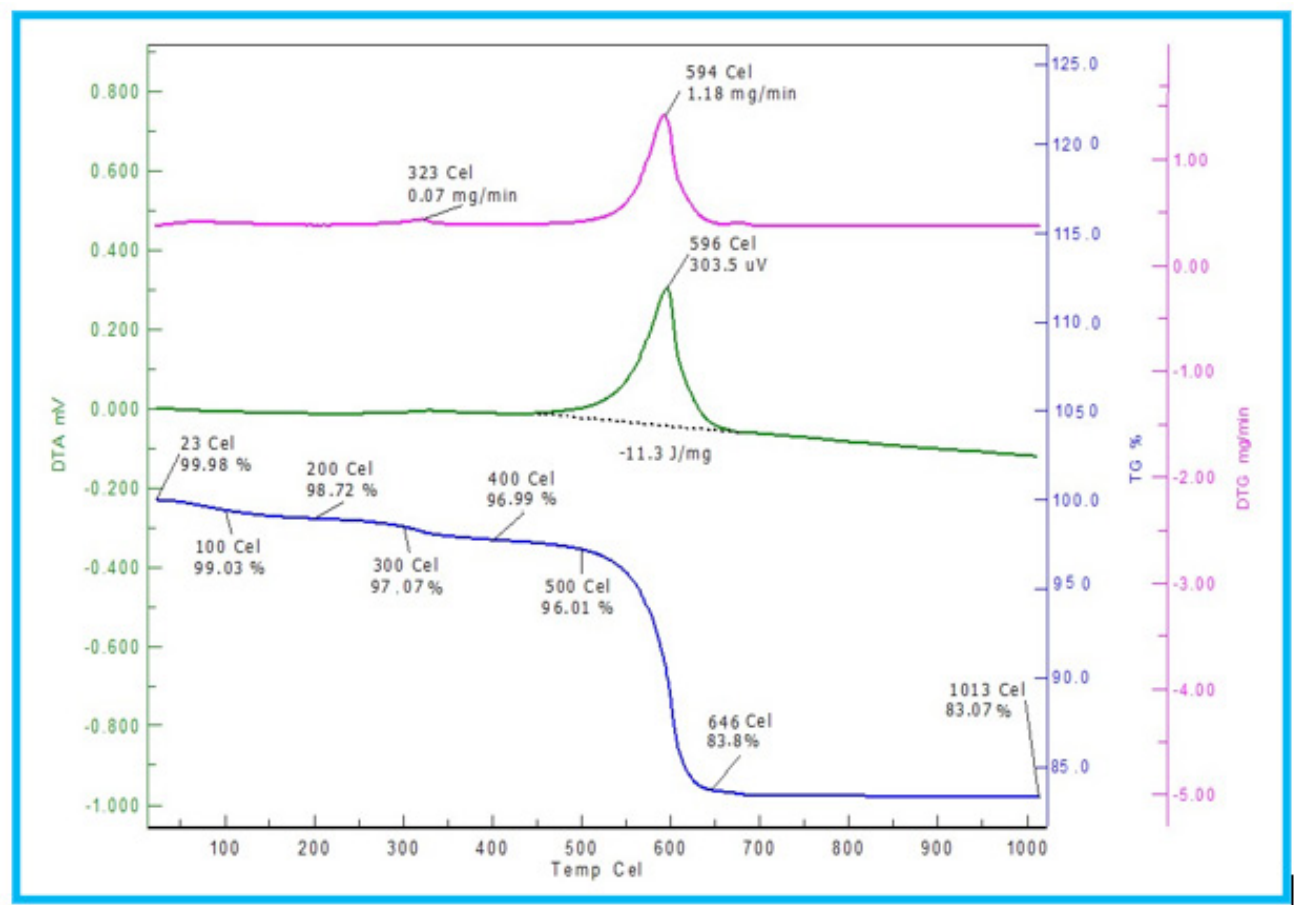

Figure 6: TGA/ DTA of fly ash

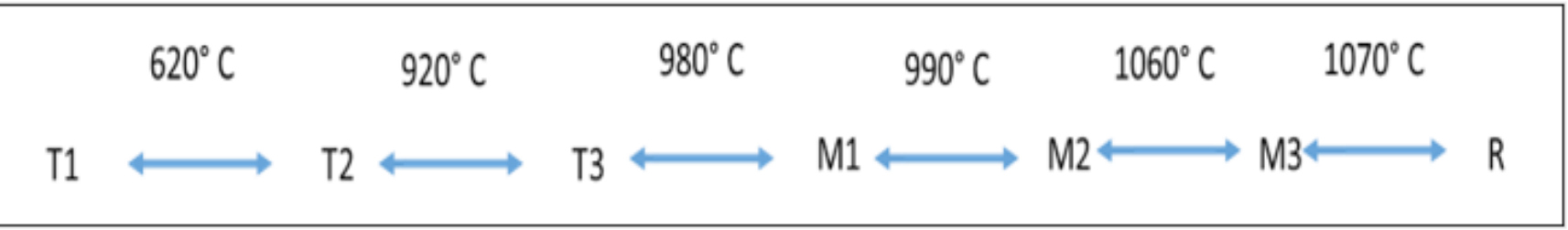

Figure 7: Synthesis temperature of different forms of alite

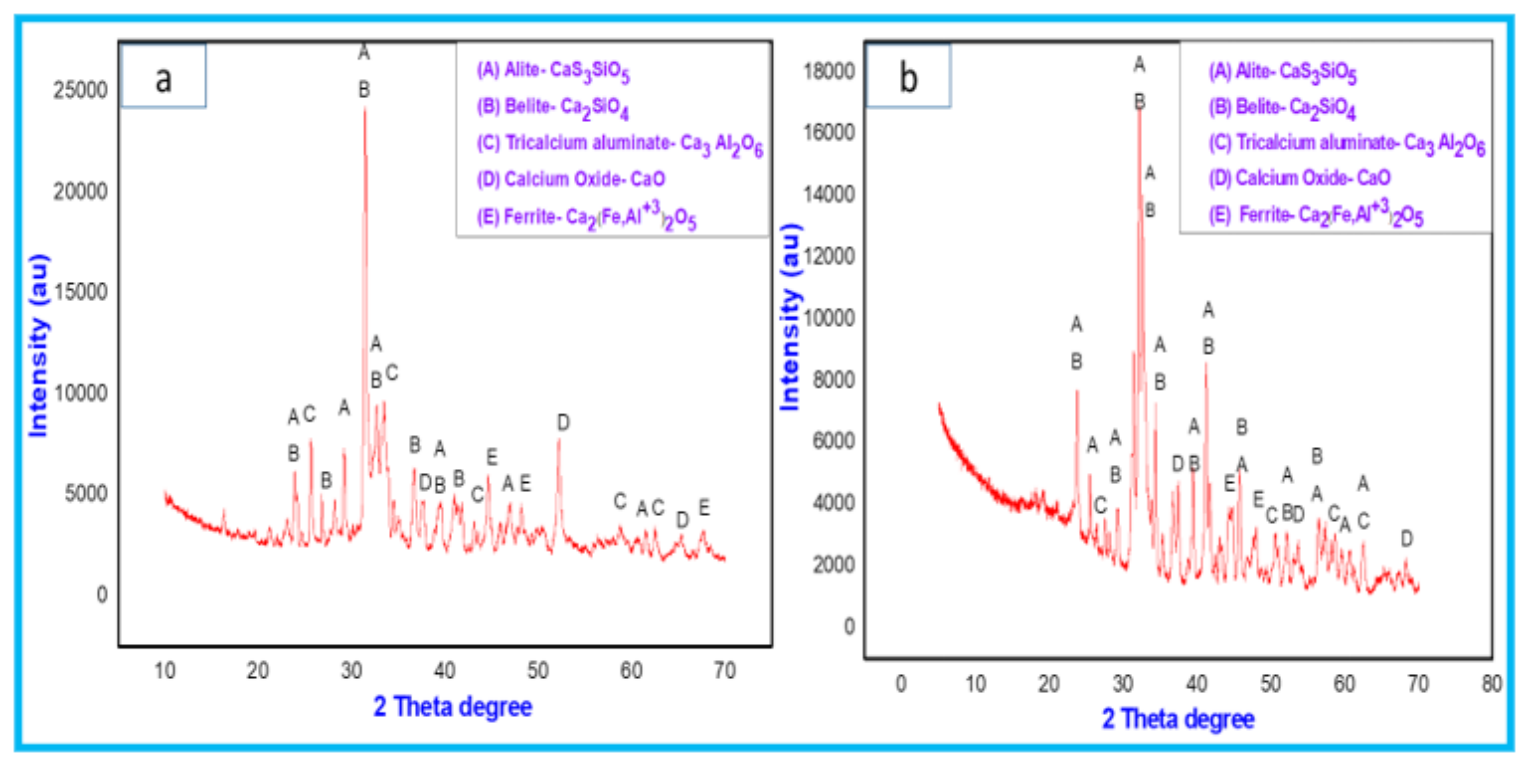

Figure 8: XRD patterns of $\mathrm{F} 1$ powder mixture fired at $1000^{\circ} \mathrm{C}$ and $1100{ }^{\circ} \mathrm{C}$. 


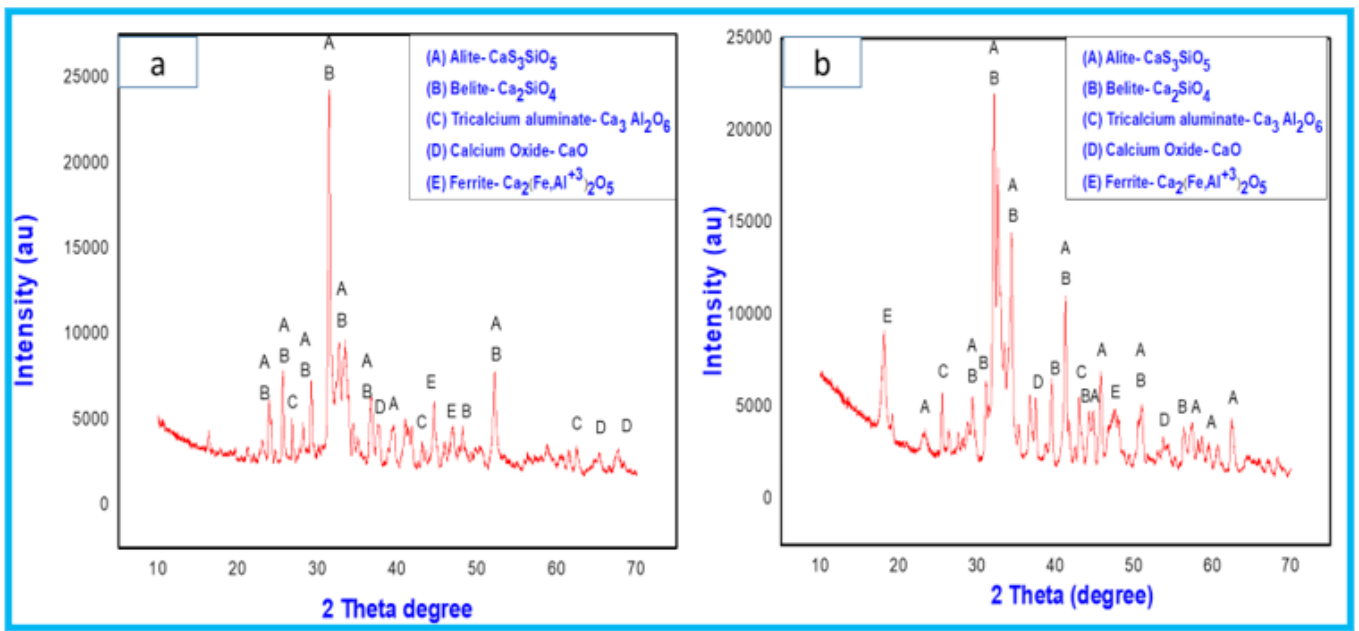

Figure 9: XRD patterns of $\mathrm{F} 2$ powder mixture fired at $1000{ }^{\circ} \mathrm{C}$ and $1100{ }^{\circ} \mathrm{C}$.

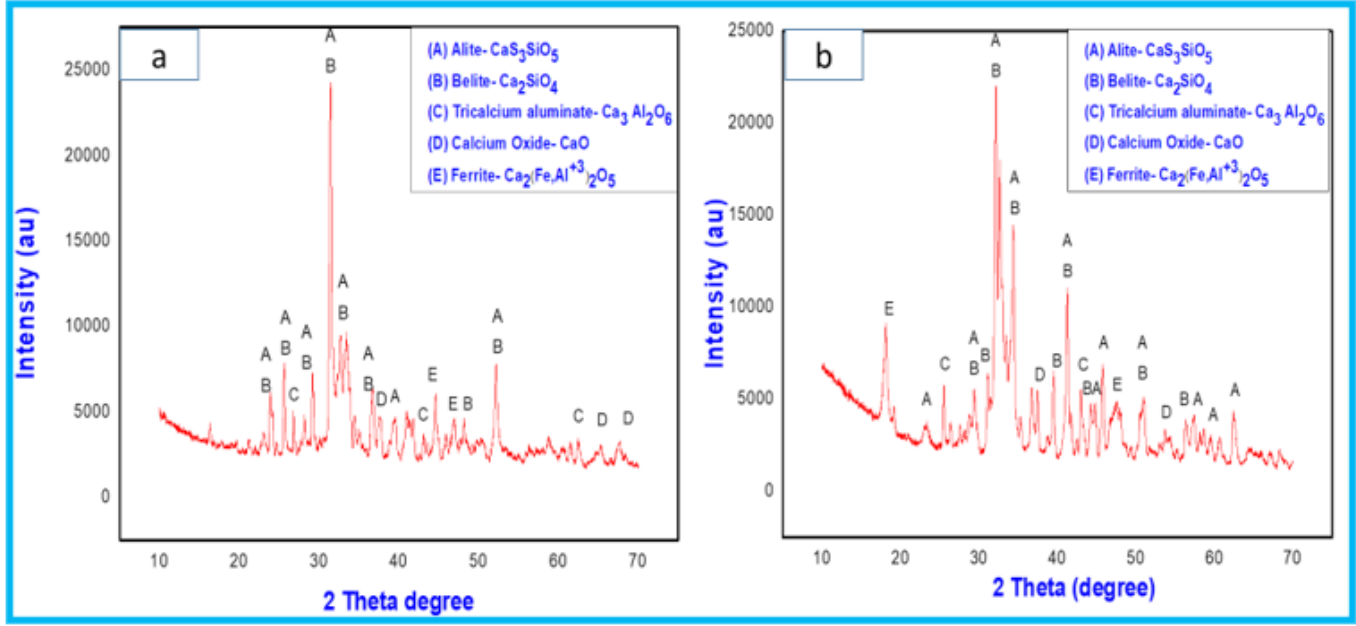

Figure 10: XRD patterns of $\mathrm{F} 3$ powder mixture fired at $1000{ }^{\circ} \mathrm{C}$ and $1100{ }^{\circ} \mathrm{C}$.

The cooling rate of the mixtures after sintering are crucial part for the stabilization of alite phases $[27,28]$. The other compounds like $\mathrm{C}_{4} \mathrm{AF}$ (ferrite) and $\mathrm{C}_{3} \mathrm{~A}$ (tricalcium aluminate) are also formed in the orthorhombic (Pcmn) and cubic (CI) polymorphic forms, respectively. The occurrence of calcium oxide peaks and their intensity in the spectrum are dependent on the percentage of lime sludge in the mixture. Figure 8 shows more peaks of calcium oxide with high intensity in comparison to Figure $9 \& 10$.

Table 4 represents the quantification results of the crystalline phases in all mixtures at different temperatures. Firing of all the mixtures at the lower temperature of $1000{ }^{\circ} \mathrm{C}$ was attempted for clinker synthesis but excess of free lime can cause cracks on the use of these products in mortar and concrete. While mixtures fired at temperature of $1100{ }^{\circ} \mathrm{C}$ resulted in less free lime and better clinker due to reaction of almost complete reaction of lime with silica and alumina. In mixture $\mathrm{F} 1$ the formation of $\mathrm{C}_{3} \mathrm{~A}$ (4.3-8.8wt. \%) and $\mathrm{C}_{4} \mathrm{AF}$ (4.4-10.3wt.\%) was relatively less than the mixtures F2 and F3 where formation of $\mathrm{C}_{3} \mathrm{~A}$ and $\mathrm{C}_{4} \mathrm{AF}$ for $\mathrm{F} 2$ were (7.3-13.8wt.\%) and (8.6-10.7wt.\%) respectively and for F3, it was (10.7-14.4wt.\%) and (8.2-13.2wt.\%). The increase in the synthesis percentage of these compounds are combined effect of temperature and formulation of the mixtures. The presence of less free $\mathrm{Al}_{2} \mathrm{O}_{3}$ and $\mathrm{Fe}_{2} \mathrm{O}_{3}$ resulted in formation of more alite and belite phases in case of F1. Due to the presence of less free and formulations the main phases formed are the typical of belitic clinkers, which consist of $\mathrm{C}_{2} \mathrm{~S}(20-65 \mathrm{wt} . \%)$ and $\mathrm{C}_{3} \mathrm{~S}$ (10-55wt.\%) [29]. Chlorides present in the fly ash eliminated during the firing treatment, which is beneficial for the durability of the clinker. In addition, the other benefits of this kind of eco-clinker is consumption of less amount of energy, which ultimately makes the product more sustainable both in economic and environmental aspect. Due to reduction in clinkering temperature, the $\mathrm{CO}_{2}$ emission can be reduced which ultimately protects the ozone layer. The maximum temperature used to prepare eco-clinker was $1100{ }^{\circ} \mathrm{C}$. The Prepared eco-clinker also has some drawbacks like hydration, hardening of eco-clinker is slow due to less alite proportion in clinker, and clinker milling is difficult [30]. 
Table 4: Crystalline phases quantification present in fired mixtures by Rietveld method.

\begin{tabular}{|c|c|c|c|c|c|c|c|}
\hline \multirow{2}{*}{ Formulation } & \multirow{2}{*}{ Temperature $\mathrm{T}_{\text {max }}\left({ }^{\circ} \mathrm{C}\right)$} & $\mathrm{C}_{3} \mathrm{~S}$ & $\mathrm{C}_{2} \mathrm{~S}$ & $\mathrm{C}_{3} \mathrm{~A}$ & $\mathrm{C}_{4} \mathrm{AF}$ & $\mathrm{CaO}$ & \multirow{2}{*}{$\chi^{2}(\%)$} \\
\hline & & \multicolumn{5}{|c|}{ (wt. \%) } & \\
\hline \multirow[t]{2}{*}{$\mathrm{F} 1$} & 1000 & 25.5 & 51.6 & 4.3 & 4.4 & 14.2 & 5.539 \\
\hline & 1100 & 38.2 & 41.3 & 8.8 & 8.3 & 3.4 & 4.643 \\
\hline \multirow[t]{2}{*}{$\mathrm{F} 2$} & 1000 & 22.7 & 48.8 & 7.3 & 8.6 & 12.6 & 6.391 \\
\hline & 1100 & 34.3 & 40.4 & 13.8 & 10.7 & 0.8 & 5.328 \\
\hline \multirow[t]{2}{*}{ F3 } & 1000 & 20.2 & 51.3 & 10.7 & 8.2 & 9.6 & 8.429 \\
\hline & 1100 & 28.5 & 42.7 & 14.4 & 13.2 & 1.2 & 6.928 \\
\hline
\end{tabular}

\section{Mortar preparation and characterization}

As discussed earlier, alite-based $\mathrm{F} 1$ clinker fired at $1100{ }^{\circ} \mathrm{C}$ was used to prepare CEM I cement (EN197-1:2011) by adding gypsum. After that, the cement was used for mortar preparation. The flowability was used to optimize the kneading water by testing the consistency. The slump value of $75 \mathrm{~mm} \pm 5 \mathrm{~mm}$ was achieved with 11.6 wt.\% of water. According to the IS: 269 , this value fulfil the requirement of specified flow value for outdoor and indoor application of mortars [31]. The prepared mortars were tested for density and compressive strength at 7 days, 28 days and 56 days. Table 11 represents the density and compressive strength of the prepared mortars. According to the results, compressive strength of the mortars increased with the progression of curing time. At the age of 7days mortars attained the compressive strength of $10 \mathrm{~N} /$ $\mathrm{mm}^{2}$ that has advanced to $18 \mathrm{~N} / \mathrm{mm}^{2}$ and $25 \mathrm{~N} / \mathrm{mm}^{2}$ at the age of 28 and 56 days respectively. According to the Indian Standards IS: 2250 (Code of practice for preparation and use of masonry mortars), the achieve strength was found suitable to use as masonry mortar [32]. The first 28 days of curing also resulted in increment in the density, but after that it remain unchanged. In addition to this, the mortars were also found suitable for efflorescence and other deleterious signs after visual examination.

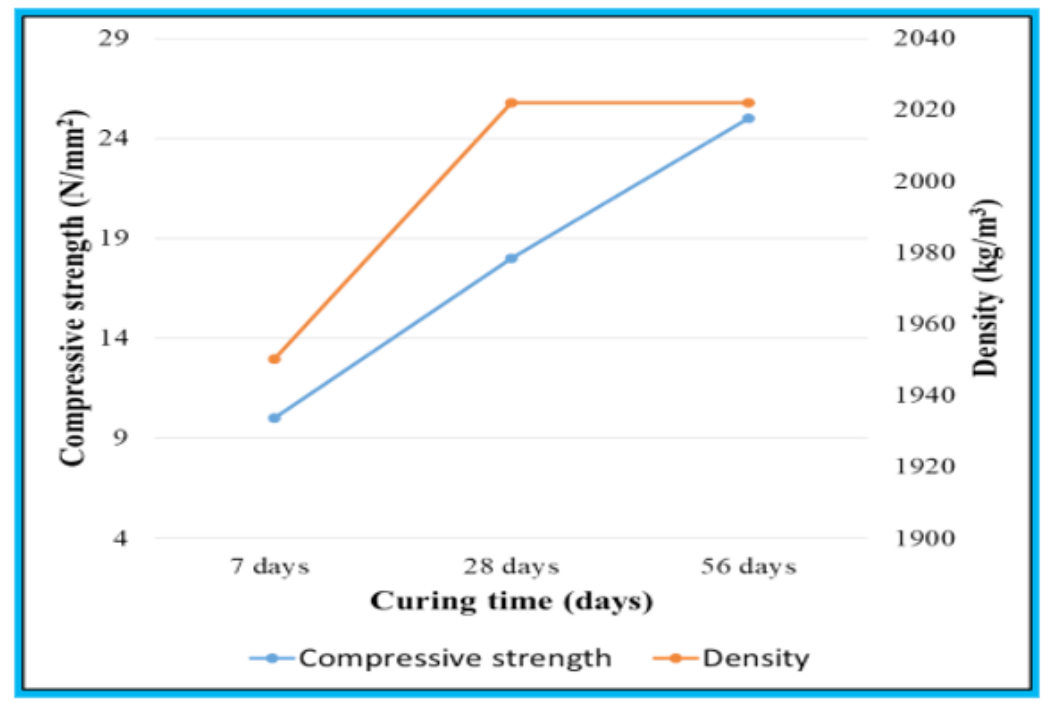

Figure 11: Progression of the compressive strength and density with curing time.

\section{Conclusion}

This study represents the possibility of the paper industry waste materials namely, lime sludge (LS) and fly ash for the utilisation of cement clinker synthesis in sustainable manner. The chemical compatibility of these wastes with the traditional raw materials made them to being utilised for clinker synthesis, as characterisation of LS and fly ash revealed that they are composed with the compounds of calcium, silica, alumina and iron. It was conceivable to formulate a large amount of LS $(\approx 60 \mathrm{wt} \%)$ and fly ash $(\approx 40 \mathrm{wt} \%)$ with the generation of clinker phases involved $\mathrm{C}_{3} \mathrm{~S}$, $\mathrm{C}_{2} \mathrm{~S}, \mathrm{C}_{3} \mathrm{~A}$ and $\mathrm{C}_{4} \mathrm{AF}$. The "eco-Portland cement clinker" produced from the firing of waste materials at $1100{ }^{\circ} \mathrm{C}$ that is very less than the temperature employed in industries $\left(\approx 1450{ }^{\circ} \mathrm{C}\right)$. This reduction in temperature is associated with the economic and environmental 
benefits. In addition, chlorides present in the fly ash eliminated during the firing treatment and do not affect the durability of the clinker. The prepared mortars also fulfilled the need of indoor and outdoor plasters. The efflorescence formation was not critical for durability issues. The Prepared eco-clinker also has some drawbacks like hydration, hardening of eco-clinker is slow due to less alite proportion in clinker, and clinker milling is difficult.

\section{Acknowledgment}

The research studies are part of FTT project of CSIR, New Delhi.

\section{References}

1. Kong L, Hasanbeigi A, Price L (2016) Assessment of emerging energyefficiency technologies for the pulp and paper industry: A technical review. Journal of Cleaner Production 122: 5-28.

2. Mamińska RT (2017) Limits and perspectives of pulp and paper industry wastewater treatment: A review. Renewable and Sustainable Energy Reviews 78: 764-772.

3. Shreve RN, Brink JA (2008) Indústrias de processos químicos. In: $\left(4^{\text {th }}\right.$ edn), Rio de Janeiro: Guanabara Koogan, Brazil.

4. Sahu V, Gayathri V (2014) The use of fly ash and lime sludge as partial replacement of cement in mortar. Int J Eng Technol Innov (IJEIT) 4: 3037.

5. Eng CR (2000) Utilisation of lime sludge for value reburning of lime sludge. National Council for Cement and Building Material, New Delhi, India.

6. Dorris GM, Allen LH (1985) The effect of reburned Lime structure on the rates of slaking, caustisizing and Lime mud setting. J Pulp Pap Sci 2: 89-97.

7. Tran EH, Vakkilainen EK (2016) The kraft chemical recovery process, pp. 1-7.

8. Talukdar DK (2015) A study of paper mill lime sludge for stabilization of village road sub-base. Int J Adv Res Technol 5: 739-746.

9. Alam M, Berera V (2015) An experimental study on use of hypo sludge in cement concrete. Int J Progr In Civil Eng 2(1): 13-23.

10. Kumar KA, Rajasekhar K, Sashidhar C (2016) Experimental investigation on fly ash and lime sludge in cement mortar. Int J Latest Technol Eng Manag Appl Sci (IJLTEMAS) 5: 2278-2540.

11. Brás I, Almeida R, Silva PC, Marques L (2016) Industrial waste valorization to produce eco-materials for construction applications. Int J Environmental Science and Development (IJESD) 7(8): 559-562.

12. Soni Y, Kumar V, Kulkarni S, Sharma P, Singh SK (2015) Lime sludge: An emerging alternate construction building material for the partial replacement of fine aggregate. AIChE Annual Meeting 8-13 Salt Lake City, USA.

13. Ampadu KO, Torii K (2002) Chloride ingress and steel corrosion in cement mortars incorporation low-quality fly ashes. Cem Concr 32: 893901.

14. Pal V, Mahla ER, Hisar OITM (2016) Study of effect of lime sludge and silica fume on strength of concrete. Int J Tech Res (IJTR) 5(2): 1-5.
15. Kumar YS, Pradesh A, Chari KJB, Surjana N (2017) Effect of strength parameters in concrete with partial replacement of cement using hypo sludge by adding fibers. Int J Civil Eng Technol (IJCIET) 8: 456-466.

16. Leire HB, Seabra MP, Labrincha JA (2015) Preparation of clinker from paper pulp industry wastes. J Hazard Mater 286: 252-260.

17. Simao L (2017) Waste-containing clinkers: Valorization of alternative mineral sources from pulp and paper mills. Process Saf Environ 109: 106-116.

18. Vashistha P, Singh SK, Dutt D, Kumar V (2019) Sustainable utilization of paper mill solid wastes via synthesis of nano silica for production of belite based clinker. J Clean Prod 224: 557-565.

19. Maroušek J (2014) Economically oriented process optimization in waste management. Environ Sci Pollut R 21(12): 7400-7402.

20. Maroušek J, Kolář L, Vochozka M, Stehel V, Maroušková A (2017) Novel method for cultivating beetroot reduces nitrate content. J Clean Prod 168: 60-62.

21. Santos RP, Martins J, Gadelha C, Cavada B, Albertini AV, et al. (2014) Coal fly ash ceramics: preparation, characterization, and use in the hydrolysis of sucrose. The Scientific World Journal, pp. 1-4.

22. Fan M, Brown RC (2001) Comparison of the loss-on-ignition and thermo gravimetric analysis techniques in measuring unburned carbon in coal fly ash. Energy \& Fuels 15(6): 1414-1417.

23. Chatterjee AK (1983) Chemico-mineralogical characteristics of raw materials. In: Ghost (Ed.), Advances in Cement Technology, Pergamon Press, Oxford, UK.

24. Noirfontaine MN, Courtial M, Dunstetter F, Gasecki G, Frehel MS (2012) Tricalcium silicate $\mathrm{Ca}_{3} \mathrm{SiO}_{5}$ superstructure analysis: a route towards the structure of the $\mathrm{M}_{1}$ polymorph. Zeitschrift Für Kristallographie Crystalline Materials 227(2): 102-112.

25. Maki I, Chromý S (1978) Microscopic study on the polymorphism of $\mathrm{Ca}_{3} \mathrm{SiO}_{5}$. Cement and Concrete Research 8(4): 407-414.

26. Regourd M (1979) Polymorphisme du silicate tricalcique. Nouvelles Données De La Diffraction Des Rayons 289(B): 17.

27. Hewlett PC, Martin L (1998) Lea's Chemistry of cement and concrete. In: ( $4^{\text {th }}$ edn), Linacre House, Jordan Hill, Oxford, UK.

28. Nettleship I, Slavick KG, Kim YJ, Kriven WM (1992) Phase transformation in dicalcium silicate: I, Fabrication and phase stability of fine-grained $\beta$ phase. J Am Ceram Soc 75: 2400-2406.

29. Lynn AC, Reitherman R (2011) Building integration solutions. In: Proceedings of AEI Conference American Society of Civil Engineers, Reston, Virginia, USA.

30. Taylor HFW (1997) Cement chemistry. In: $\left(2^{\text {nd }}\right.$ edn), Thomas Telford Publishing, London, UK.

31. IS: 269 (2015) Ordinary Portland cement-specification. Bureau of Indian Standards, New Delhi, India.

32. I.S. 2250 (1981) Indian standard code of practice for preparation and use of masonry mortars. Bureau of Indian Standards, New Delhi, India.

For possible submissions Click below:

Submit Article 